Vol. 5, No. 2, 2020, pp. 63-68

DOI: https://doi.org/10.29210/02626jpgi0005

Contents lists available at Џournal IICET

JPGI (Jurnal Penelitian Guru Indonesia)

ISSN: 2541-3163(Print) ISSN: 2541-3317 (Electronic)

Journal homepage: https://jurnal.iicet.org/index.php/ipgi

\title{
Peningkatan keterampilan wudhu dan tayamum pada mata pelajaran Pendidikan Agama Islam (PAI) dengan menggunakan metode demonstrasi
}

\author{
Murhasneli Murhasneli \\ SDN 05 Air Pura Kecamatan Air Pura
}

\begin{tabular}{l} 
Article Info \\
\hline Article history: \\
Received Jul $20^{\text {th }}, 2020$ \\
Revised Aug $17^{\text {th }}, 2020$ \\
Accepted Sep $21^{\text {st }}, 2020$ \\
\hline Keyword: \\
Wudhu \\
Tayamum \\
Pendidikan Agama Islam \\
Metode demostrasi
\end{tabular}

\begin{abstract}
Kajiannya dilatar belakangi karena banyak siswa kelas IV yang belum bisa melaksanakan wudhu dan tayamum dengan baik dan benar. Hal ini terlihat dari perolehan nilai praktek yang belum mencapai KKM. Dari 34 siswa dikelas IV hanya 18 siswa atau 53\% yang tuntas KKM, berarti masih ada 16 siswa yang belum tuntas pada materi wudhu. Sedangkan dalam materi tayamum dari 34 siswa hanya 11 siswa atau $33 \%$ yang tuntas $\mathrm{kkm}$ dalam melaksanakan praktek tayamum berarti masih ada 23 siswa yang belum tuntas KKM. Peneliti berupaya keras untuk melakuka perbaikan dalam pembelajaran wudhu dan tayamum melalui Penelitian Tindakan Kelas (PTK) dengan menggunakan metode demonstrasi melalui dua siklus. Hasil penelitian perbaikan pembelajaran mengalami peningkatan pada materi wudhu dari pembelajaran awal 53\% meningkat menjadi $68 \%$ disiklus I dan meningkat menjadi $94 \%$ pada siklus II. Sedangkan pada materi tayamum mengalami peningkatan dari pembelajaran awal 33\% menjadi 50\% disiklus I dan meningkat menjadi $94 \%$ pada siklus II. Dengan demikian perbaikan pembelajaran PAI pada materi wudhu dan tayamum menggunakan metode demonstrasi dapat meningkatkan keterampilan siswa dalam melaksanakan wudhu dan tayamum. Sehingga peneliti memutuskan untuk mengakhiri Penelitian Tindakan Kelas hanya sampai pada siklus II saja.
\end{abstract}

(C) 2020 The Authors. Published by IICET.

This is an open access article under the CC BY-NC-SA license

(https://creativecommons.org/licenses/by-nc-sa/4.0

\section{Corresponding Author:}

Murhasneli Murhasneli,

SDN 05 Air Pura Kecamatan Air Pura

Email: murhasneli@gmail.com

\section{Pendahuluan}

Guru merupakan ujung tombak dalam pendidikan, yang secara langsung mempengaruhi, membina dan mengembangkan serta membimbing dan mengarahkan kemana tujuan yang hendak di capai dan harus ditempuhnya, dalam membentuk seseorang yang cerdas, terampil, dan bermoral tinggi. Inilah hakikat pendidikan sebagai usaha untuk menjadikan siswa sebagai manusia yang dewasa baik jasmani dan rohani. Kemampuan tercermin dalam kompetensi guru, sebagai pengajar paling tidak guru harus menguasai bahan yang diajarkannya dan terampil dalam hal cara mengajar. Berdasarkan hasil observasi pendahuluan yang dilaksanakan 
pada tanggal 11 September 2019 di UPT. SDN 05 Air Pura Kecamatan Air Pura tepatnya kelas IV peneliti menemukan beberapa masalah diantaranya: 1). Siswa tidak bisa melakukan praktek wudhu dan tayamum dengan baik dan benar. 2). Masih banyak kekeliruan dalam melakukan praktek wudhu dan tayamum. 3).masih banyak siswa yang belum hafal niat wudhu dan tayamum. 4). Adanya siswa yang tidak mau bertanya padahal belum paham mengenai materi wudhu dan tayamum. Dari beberapa masalah yang timbul, tampaknya masalah siswa tidak bisa melakukan praktek wudhu dan tayamum dengan baik dan benar merupakan masalah yang paling dominan. Hal ini terbukti ketika guru menilai praktek wudhu dan tayamum masih banyak siswa yang tidak bisa praktek wudhu dan tayamum dengan baik dan benar.

Untuk memperbaiki kualitas pemelajaran PAI dalam materi wudhu dan tayamum, peneliti mencoba menggunakan metode demonstrasi untuk menjelaskan tata cara berwudhu dan bertayamum yang baik dan benar. Dengan menggunakan metode demonstrasi diharapkan mampu meningkatkan keterampilan wudhu dan tayamum sebagai bahan penelitian perbaikan melalui Penelitian Tindakan Kelas.

Berdasarkan ilustrasi diatas, peneliti berencana mengadakan penelitian tindakan kelas untuk memperbaiki kualitas pembelajaran PAI materi wudhu dan tayamum di UPT. SDN 05 Air Pura Kecamatan Air Pura tahun pelajaran 2018/2019.

\section{Metode}

Bentuk Penelitian Tindakan Kelas yang digunakan yaitu Penelitian Tindakan Kelas Kolaboratif, yakni peneliti bekerjasama dengan guru kelas IV UPT. SDN 05 Air Pura Kecamatan Air Pura Kabupaten Pesisir Selatan. Penelitian Tindakan Kelas yang sedang diteliti mengambil mata pelajaran Pendidikan Agama Islam (PAI) materi wudhu dan tayamum dengan menggunakan metode demonstrasi.

Penelitian ini dilakukan di kelas IV UPT. SDN 05 Air Pura Kecamatan Air Pura Kabupaten Pesisir Selatan, mulai tanggal 22 Juli 2019 sampai tanggal 22 Agustus 2019. Teknik pengumpulan data menggunakan tes, observasi, wawancara dan dokumentasi.Dalam penelitian ini yang menjadi subjek penelitian adalah seluruh siswa kelas IV UPT. SDN 05 Air Pura Kecamatan Air Pura Kabupaten Pesisir Selatan tahun pelajaran 2018/ 2019 yang berjumlah 34 anak. Yang terdiri dari siswa laki-laki 13 dan perempuan 21.

Analisis data dilakukan setiap kali pemberian tindakan berakhir dan sesudah pengumpulan data. Berdasarkan data dari lembar observasi, serta daftar nilai PAI, kemudian dilakukan analisis. Analisis data dilakukan selama proses penelitian berlangsung dan sampai penelitian selesai. Analisis deskriptif dilakukan terhadap data yang bersifat kuantitatif. Semua data dikaji dan dibahas oleh penulis, selanjutnya dilakukan refleksi dan ditarik kesimpulan. Sedangkan untuk data kuantitatif, analisis datanya adalah dengan menggunakan rumus tertentu yang bertujuan untuk mengetahui presentasi keberhasilan pembelajaran PAI pada tema wudhu dan tayamum dengan menggunakan metode demonstrasi. Kegiatan dirancang dengan penelitian tindakan kelas dengan siklus. Setiap siklus terdiri dari perencanaan, pelaksanaan, pengamatan, dan refleksi. Penelitian dilaksanakan dalam dua siklus. Idikator keberhasilan disini adalah sebagai tolak ukur keberhasilan siswa dalam melaksanakan pembelajaran Pendidikan Agama Islam (PAI) materi wudhu dan tayamum dengan menggunakan metode demonstrasi.

\section{Hasil dan Pembahasan}

Penelitian Tindakan Kelas ini dilaksanakan dalam dua siklus, yaitu siklus I dan siklus II. Setiap akhir siklus diadakan evaluasi untuk mengetahui hasil pembelajaran keterampilan siswa terhadap materi yang diajarkan. Siswa yang tuntas melakukan praktek wudhu adalah 18 siswa atau 53\% sedangkan yang belum tuntas adalah 16 siswa atau $47 \%$. Dari tabel 9 dapat dilihat banyaknya siswa yang tuntas melakukan praktek tayamum adalah 11 siswa atau 32,50\% sedangkan yang belum tuntas adalah 23 siswa atau 67,50\% .

\section{Siklus Pertama Materi Wudhu \\ Perencanaan}

Pelaksanaan tindakan siklus pertama dilakukan pada tanggal 29 Juli 2019. Berdasarkan perencanaan pembelajaran, penulis menyiapkan beberapa bahan atau peralatan untuk menunjang proses pembelajaran 
selama penelitian yaitu: replika air yang terbuat dari tali rafia sebagai media dalam mendemonstrasikan wudhu.

\section{Pelaksanaan}

Pelaksanaan pada siklus pertama ini guru memulai dengan menyampaikan kepada siswa bahwa hari ini akan mempraktikan wudhu, apa tujuan yang harus dicapai oleh siswa serta menghubungkan pelajaran yang lalu (sebelim tindakan) dengan pelajaran yang akan dipelajari.

Setelah selesai guru memanggil siswa dan siswa maju ke depan sesuai dengan nama yang terpanggil. Dalam melalukan praktik ini, untuk menghemat waktu guru memanggil lima siswa sekaligus untuk melakukan praktik wudhu secara bersamaan dan guru bertindak sebagai pembimbing terhadap siswa. Selama praktik dilakukan, selalin peneilti sebagai guru juga terdapat guru lain sebagai observer. Tugas dari observer ini adalah mengobservasi atau menilai kegiatan guru dan kegiatan siswa sesuai format yang telah dibuat selama pembelajaran. Ketika siswa melakukan praktik wudhu, guru langsung memberikan penilaian kepada siswa terhadap praktik yang dilakukannya. Penilaian yang diberikan kepada siswa adalah sesuai dengan indikator keberhasilan siswa dalam belajar. Indikator tersebut terdiri dari sembilan yang akan dinilai, yaitu mulai dari membaca bismillah sampai kepada membaca do'a selesai berwudhu.

\section{Observasi}

Tabel 1. Hasil observasi kegiatan guru

\begin{tabular}{lll}
\hline No & \multicolumn{1}{c}{ Aktivitas Guru } & \multicolumn{1}{c}{ Keterangan } \\
\cline { 3 - 3 } $\mathbf{1}$ & \multicolumn{1}{c}{$\begin{array}{c}\text { Guru menyediakan replica air } \\
\text { Ketika guru masuk kelas, guru menyampaikan kepada siswa bahwa hari ini } \\
\text { akan belajar praktek Wudhu. }\end{array}$} & $\sqrt{ }$ \\
$\mathbf{3}$ & $\begin{array}{l}\text { Setelah itu guru mengemukakan tujuanapa yang harus dicapai oleh siswa } \\
\mathbf{4}\end{array}$ & $\begin{array}{l}\text { Kemudian menjelaskan hal-hal apa saja yang harus dilakukan oleh siswa } \\
\text { ketika belajar praktik berwudhu }\end{array}$ \\
$\mathbf{5}$ & $\begin{array}{l}\text { Sebelum siswa mempraktikan wudhu terlebih dahulu guru sedikit } \\
\text { menjelaskan tentang wudhu yang harus diketahui siswa }\end{array}$ & $\sqrt{ }$ \\
$\mathbf{6}$ & $\begin{array}{l}\text { Kemudian guru menyuruh seluruh } \\
\text { siswa keluar untuk melaksanakan } \\
\text { praktik wudhu }\end{array}$ & $\sqrt{ }$ \\
$\mathbf{7}$ & $\begin{array}{l}\text { Sebelumnya guru mencontohkan bagaimana caranya berwudhu yang baik } \\
\text { dan benar kepada siswa. }\end{array}$ & $\sqrt{ }$ \\
$\mathbf{8}$ & $\begin{array}{l}\text { Setelah selesai guru menyuruh siswasatu persatu untuk melakukan praktek } \\
\text { wudhu }\end{array}$ & $\sqrt{ }$ \\
\hline
\end{tabular}

Dari hasil observasi kegiatan guru tersebut sudah terlaksana dengan baik, namun karena metode ini adalah metode demonstrasi maka banyak waktu yang tersita karena harus menyiapkan peralatan yang harus digunakan untuk melakukan praktek demonstrasi. Adapun hasil observasi kegiatan siswa dapat dilihat pada Indikator: 1) Membasuh telapak tangan sambil mengucapkan Bismillahir Rahmanir Rahim; 2) Berkumur-kumur 3x ; 3) Membersihkan lubang hidung; 4) Membasuh muka sebanyak 3x mulai dari tumbuhnya rambut kepala sampai ke dagu sambil membaca niat wudhu Nawaitul wudhuu'a li raf'il hadatsil ashghari fardhal lillahi ta'ala; 5) Membasuh tangan sampai siku; 6) Membasuh sebagian kepala dan telinga; 7) Membasuh kaki sampai dengan mata kaki; 8) Membaca doa setelah wudhu; 9) Tertib.

Dari hasil observasi siklus 1 dapat dilihat bahwa siswa sudah melakukan kegiatan demonstrasi dengan baik, meskipun masih terdapat kekurangan pada siswa khususnya pembacaan do'a serta tidak sampainya siswa menyapu tangan sampai ke siku serta tidak ratanya membasuh muka. Tetapi secara keseluruhan sudah bagus. Setelah diadakan perbaikan dapat nilai rata-rata 70,5.

Journal homepage: https://jurnal.iicet.org/index.php/jpgi 


\section{Siklus Pertama Materi Tayamum \\ Perencanaan}

Pelaksanaan tindakan siklus pertama pada materi tayamum dilakukan pada tanggal 12 Agustus 2019. Berdasarkan perencanaan pembelajaran, penulis menyiapkan beberapa bahan atau peralatan untuk menunjang proses pembelajaran selama penelitian yaitu: debu yang menempel di meja belajar sebagai alat yang digunakan untuk bertayamum.

\section{Pelaksanaan}

Pelaksanaan pada siklus pertama ini guru memulai dengan menyampaikan kepada siswa bahwa hari ini akan mempraktikan tayamum, apa tujuan yang harus dicapai oleh siswa serta menghubungkan pelajaran yang lalu (sebelum tindakan) dengan pelajaran yang akan dipelajari. Sebelum siswa mempraktikan tayamum, guru di kelas menerangkan secara ringkas pengetahuan sekitar tentang tayaum yang harus diketahui oleh siswa. Setelah seleasai maka setiap siswa melakukan praktik tayamum. Namun, sebelum siswa satu persatu melakukan praktik, guru mempraktikan terlebih dahulu betayamum secara baik dan benar.

Setelah selesai guru memanggil siswa dan siswa maju ke depan sesuai dengan absen. Penilaian yang diberikan kepada siswa adalah sesuai dengan indikator keberhasilan siswa dalam belajar. Indikator tersebut terdiri dari sembilan yang akan dinilai, yaitu mulai dari membaca bismillah sampai kepada membaca do'a selesai bertayamum. Setelah praktik tayamum telah selesai, guru bersama siswa membuat kesimpulan dari hasil praktik tersebut. Kemudian guru memberikan tugas kepada siswa agar melakukan praktik tayamum di rumah sesuai dengan apa yang telah diajarkan. Dalam memberikan tugas guru menyebutkan faedah dari tayamum itu sendiri sehingga siswa lebih bersemangat.

\section{Observasi}

Observasi dilakukan dengan mengamati proses pembelajaran yang berlangsung selama penelitian dilakukan. Dalam penelitian yang bertindak sebagai pengamat adalah guru kelas IV bernama Aneka Emi Wijayanti. S.Pd.SD. Observasi dilakukan untuk melihat proses pembelajaran yang dilakukan oleh guru dan kegiatan yang dilakukan oleh siswa. Kegiatan yang dilakukan oleh observer pada penelitian ini adalah mengobservasi kegiatan guru dan siswa.

Dari hasil observasi kegiatan guru tersebut sudah terlaksana dengan baik, namun karena metode ini adalah metode demonstrasi maka banyak waktu yang tersita karena harus menyiapkan peralatan yang harus digunakan untuk melakukan praktek demonstrasi. Adapun hasil observasi kegiatan siswa dapat dilihat pada Indikator: 1) Meletakan telapak tangan diatas meja sambil mengucapkan Bismillahir Rahmanir Rahim; 2) Menepuknepukan punggung tangan dengan tujuan untuk menipiskan debu yang hendak digunakan untuk tayamum; 3) Mengusap muka sebanyak 1x mulai dari tumbuhnya rambut kepala sampai kedagu sambil melafalkan niat tayamum Nawaitut Tayammuma Listibaahatish Sholati Fardhol lillahi Ta'alaa; 4) Meletakan telapak tangan diatas meja yang digunakan untuk bertayamum tetapi ditempat yang berbeda dari tempat yang pertama; 5) Menepuk-nepukan punggung tangan dengan tujuan untuk menipiskan debu yang hendak digunakan untuk tayamum; 6) Mengusap tangan sampai siku 1x secara bergantian dimulai dari tangan sebelah kanan; 7) Mengusap sela-sela jari dengan kedua tangan; 8) Membaca doa setelah tayamum; 9) Tertib

Dari hasil observasi siklus 1 dapat dilihat bahwa siswa sudah melakukan kegiatan demonstrasi dengan baik, meskipun masih terdapat kekurangan pada siswa khususnya pembacaan do'a serta tidak sampainya siswa menyapu tangan sampai ke siku serta tidak ratanya menyapu muka. Tetapi secara keseluruhan sudah bagus. Hasil Perbaikan Pembelajaran Siklus I Materi Tayamum rata-rata 71,76.

Setelah perbaikan pembelajaran yang dilakukan pada siklus pertama, banyaknya siswa yang tuntas KKM dalam pembelajaran PAI materi wudhu mencapai 23 siswa atau $68 \%$ dari 34 siswa dan yang belum tuntas ada 11 siswa atau 32\%. Kemudian penulis melakukan analisis terhadap hasil praktek harian yang telah dilakukan guru. Setelah perbaikan pembelajaran yang dilakukan pada siklus pertama, banyaknya siswa yang tuntas KKM dalam pembelajaran PAI materi tayamum mencapai 17 siswa atau 50\% dari 34 siswa dan yang belum tuntas ada 17 siswa atau 50\%. Kemudian penulis melakukan analisis terhadap hasil praktek harian yang telah dilakukan guru. Nilai praktik tayamum rata-rata disiklus I adalah 60,29 


\section{Refleksi}

Dari hasil pelaksanaan perbaikan pembelajaraan siklus I ternyata siswa yang tuntas pada materi wudhu ada 23 siswa atau $68 \%$ dari 34 siswa, berarti masih ada 11 siswa atau $32 \%$ yang belum tuntas dalam pelaksanaan praktek wudhu. Sedangkan dalam pembelajaran tayamum ada 17 siswa atau $50 \%$ dari 34 siswa yang tuntas KKM dan masih tersiswa 17 anak atau 50\% lagi yang masih belum mencapai batas Kriteria

Ketuntasan Minimal (KKM). Dan berdasarkan hasil observasi kegiatan guru yang dilakukan oleh teman sejawat menunjukan bahwa belum semua kegiatan guru sesuai dengan yang diharapkan. Sedangkan dalam kegiatan siswa masih ada 19 siswa yang aktif mengikuti kegiatan pembelajaran. Sehingga penulis bersama observer menganalisis dan merefleksi untuk menentukan langkah-langkah perbaikan pada siklus kedua.

\section{Siklus Kedua Materi Wudhu \\ Perencanaan}

Berdasarkan hasil refleksi yang dilakukan, peneliti merencanakan beberapa hal, yaitu: (1) Memotivasi siswa agar belajar sungguh-sungguh; (2) Meminta siswa agar benar-benar memperhatikan guru ketika mendemonstrasikan wudhu; (3) Meminat siswa agar memperhatikan ketika siswa lain mempraktikan wudhu.

\section{Pelaksanaan}

Pelaksanaan pada siklus kedua tidak jauh beda dengan siklus pertama karena metode yang digunakan sama. Namun sebelum pelaksanan dilakukan guru menyampaikan siswa harus belajar sungguh-sungguh supaya mendapat nilai yang lebih bagus, siswa harus benar-benar memperhatikan guru ketika mendemonstrasikan wudhu, siswa hasus memperhatikan ketika siswa lain mempraktikan wudhu.

\section{Observasi}

Observasi dilakukan dengan mengamati proses pembelajaran yang berlangsung selama penelitian dilakukan. Dalam penelitian yang bertindak sebagai pengamat adalah guru kelas IV yaitu Aneka Emi Wijayanti. S.Pd.SD. Observasi dilakukan untuk melihat proses pembelajaran yang dilakukan oleh guru dan kegiatan yang dilakukan oleh siswa. Kegiatan yang dilakukan oleh observer pada penelitian ini adalah mengobservasi kegiatan guru dan siswa.

Adapun hasil observasi kegiatan siswa dapat dilihat pada Indikator: 1) Membasuh telapak tangan sambil mengucapkan Bismillahir Rahmanir Rahim; 2) Berkumur-kumur 3x; 3) Membersihkan lubang hidung; 4) Membasuh muka sebanyak 3x mulai dari tumbuhnya rambut kepala sampai ke dagu sambil membaca niat wudhu Nawaitul wudhuu'a li raf'il hadatsil ashghari fardhal lillahi ta'ala; 5) Membasuh tangan sampai siku; 6) Membasuh sebagian kepala dan telinga; 7) Membasuh kaki sampai dengan mata kaki; 8) Membaca doa setelah wudhu; 9) Tertib.

Dari hasil observasi siklus II dapat dilihat bahwa siswa sudah melakukan kegiatan demonstrasi dengan baik dan terjadi peningkatan dari siklus pertama meskipun masih terdapat kekurangan pada siswa khususnya pembacaan do'a .Tetapi secara keseluruhan sudah bagus. Dan Hasil Perbaikan Pembelajaran Siklus II Materi Wudhu nilai rata-rata 70.5

\section{Siklus Kedua Materi Tayamum. \\ Perencanaan}

Berdasarkan hasil refleksi yang dilakukan, peneliti merencanakan beberapa hal, yaitu: (1) Memotivasi siswa agar belajar sungguh-sungguh; (2) Meminta siswa agar benar-benar memperhatikan guru ketika mendemonstrasikan tayamum; (3) Meminta siswa agar memperhatikan ketika siswa lain mempraktikan tayamum.

\section{Pelaksanaan}

Pelaksanaan pada siklus kedua tidak jauh beda dengan siklus pertama karena metode yang digunakan sama. Namun sebelum pelaksanan dilakukan guru menyampaikan siswa harus belajar sungguh-sungguh supaya mendapat nilai yang lebih bagus, siswa harus benar-benar memperhatikan guru ketika mendemonstrasikan tayamum, siswa hasus memperhatikan ketika siswa lain mempraktikan tayamum.

\section{Observasi}

Observasi dilakukan dengan mengamati proses pembelajaran yang berlangsung selama penelitian dilakukan. Dalam penelitian yang bertindak sebagai pengamat adalah guru kelas IV yaitu Aneka Emi Wijayanti. S.Pd.SD. Observasi dilakukan untuk melihat proses pembelajaran yang dilakukan oleh guru dan kegiatan yang 
dilakukan oleh siswa. Kegiatan yang dilakukan oleh observer pada penelitian ini adalah mengobservasi kegiatan guru dan siswa.

Dari hasil observasi siklus II dapat dilihat bahwa siswa sudah melakukan kegiatan demonstrasi dengan baik dan terjadi peningkatan dari siklus pertama meskipun masih terdapat kekurangan pada siswa khususnya pembacaan do'a .Tetapi secara keseluruhan sudah bagus

Dari tabel 20 dapat dilihat bahwa setelah diadakan perbaikan pembelajaran pada siklus II pada pembelajaran wudhu siswa yang tuntas KKM mencapai 32 atau 94\% sementara siswa yang belum tuntas hanya 2 siswa atau $6 \%$. Sedangkan pada tabel 23 setelah diadakan perbaikan pembelajaran pada materi tayamum didapati siswa yang tuntas KKM ada 32 siswa atau 94\% sedangkan yang belum tuntas hanya 2 anak atau $6 \%$. Nilai praktik tayamum rata-rata disiklus II adalah 82

\section{Refleksi}

Melihat data hasil pelaksanaan perbaikan pembelajaran pada siklus kedua ini,ternyata didapati siswa yang tuntas dalam pembelajaran PAI materi wudhu mencapai 94\% atau sekitar 32 anak. Sedangkan yang masih belum tuntas KKM ada 2 siswa atau sekitar 6\%. Sedangkan pada materi tayamum sisiwa yang tuntas KKM mencapai 32 siswa atau $94 \%$ dan yang belum tuntas hanya 2 siswa atau $6 \%$. Ini berarti pelaksanaan perbaikan pembelajaran pada siklus kedua sudah memenuhi kriteria keberhasilan sehingga penulis beserta observer memutuskan bahwa perbaikan dapat dihentikan pada siklus kedua.

\section{Pembahasan}

\section{Siklus Pertama}

Dari data hasil perbaikan pada siklus pertama nilai ketuntasan belajar siswa ternyata mengalami peningkatan dibandingkan dengan studi awal. Peningkatan ketuntasan belajar siswa peneliti sajikan sebagai berikut. Dari hasil penilaian harian dapat diketahui dari 34 siswa kelas IV UPT. SDN 05 Air Pura Kecamatan Air Pura ada 23 siswa yang nilai praktek wudhunya sudah memenuhi KKM sedangkan untuk praktek tayamumnya ada 16 siswa yang lulus KKM. Jadi prosentase keterampilan wudhu siswa sebesar $68 \%$ sementara prosentase keterampilan tayamum siswa sebesar $50 \%$.

\section{Siklus Kedua}

Dari perolehan data hasil perbaikan pada siklus kedua, penulis mendapati adanya peningkatan keterampilan belajar siswa dibandingkan dengan studi awal dan siklus pertama. Peningkatan ketuntasan belajar siswa tersebut penulis sajikan sebagai berikut.

Dari hasil penilaian harian dapat diketahui dari 34 siswa kelas IV UPT. SDN 05 Air Pura Kecamatan Air Pura ada 32 siswa yang nilai praktek wudhunya sudah memenuhi KKM sedangkan untuk praktek tayamumnya ada 32 siswa yang lulus KKM. Prosentase keterampilan wudhu siswa sebesar 94\%. Sementara prosentase keterampilan tayamum siswa sebesar $94 \%$

\section{Pembahasan Antar Siklus}

Dalam pembahasan antar siklus, penulis sajikan data hasil penilaian sehari-hari sebelum dilakukan tindakan, hasil penilaian siklus I, dan hasil penilaian siklus II. Dari hasil analisis yang penulis lakukan, dapat dilihat bahwa terjadi peningkatan keterampilan belajar secara keseluruhan di kelas. Dari selisih nilai awal dan nilai ahir sesudah dilakukan tindakan dapat dilihat peningkatan keterampilan peserta didik naik secara keseluruhan. Nilai rata-rata juga mengalami kenaikan, nilai rata-rata materi wudhu 65,8 sebelum dilakukan tindakan meningkat menjadi 70,5 pada siklus I dan meningkat lagi menjadi 82 pada siklus II. Sedangkan pada materi tayamum 49,70 sebelum dilakukan tindakan, meningkat menjadi 60,29 disiklus I dan meningkat menjadi 82 pada siklus II.

\section{Simpulan}

Berdasarkan hasil pelaksanaan perbaikan pembelajaran yang telah dilaksanakan, penulis dapat menarik kesimpulan sebagai berikut: Penggunaan metode demonstrasi dalam pembelajaran wudhu dan tayamum mampu memberikan pengalaman yang menyenangkan pada siswa sehingga terjadi peningkatan keterampilan peserta didik dalam melakukan wudhu dan tayamum serta keaktifan siswa dalam mengikuti pembelajaran meningkat seperti yang diharapkan.hal ini bisa dilihat dari prosentase peningkatan ketuntasan belajar sebagai berikut: (1) Pada materi wudhu studi awal menunjukan bahwa peserta didik yang tuntas KKM 53\% 
atau 18 siswa. Pada siklus I yang tuntas KKM mencapai 68\% atau 23 siswa. Sedangkan pada siklus II ketuntasan mencapai $94 \%$ atau 32 siswa; (2) Pada materi tayamum studi awal menunjukan bahwa siswa yang tuntas hanya $32 \%$ atau 11 siswa, pada siklus I mencapai $50 \%$ atau 17 siswa, sedangkan pada siklus II mencapai 94\% atau 32 siswa. Setelah dilakukan penelitian di UPT. SDN 05 Air Pura Kecamatan Air Pura dan berdasarkan hasil yang diperoleh dari lapangan, maka penulis mengajukan saran-saran sebagai berikut: 1) Bagi guru, dalam pembelajaran Pendidikan Agama Islam guru memerlukan metode yang berfariasi sehingga dapat meningkatkan semangat belajar siswa. Dan dapat mempermudah mencapai tujuan pembelajaran yang diinginkan; 2) Kepada semua pihak di sekolah tertama para guru, sudah seharusnya meningkatkan kompetensi professional serta membekali diri dengan pengetahuan yang luas, karena kompetensi yang dimiliki oleh guru sangat berpengaruh pada keberhasilan proses pembelajaran sehingga dapat menghasilkan siswa yang berprestasi, berbudi luhur dan dapat memajukan prestasi sekolah.

\section{Referensi}

Arief, Armai. (2002). Pengantar Ilmu dan Metodologi Pendidikan Islam. Jakarta: Ciputat Pers Darajat, Zakiyah. (2006). Ilmu Pendidikan Islam. Jakarta: CV.Pustaka Agung Harapan

Daryanto. (2009). Panduan Proses Pembelajaran Kreatif dan Inofatif Teori dan Praktik Dalam Pengembangan Profesionalisme Bagi Guru. Jakarta: AV Publisher

Fuad Efendi, Ahmad. (2005). Metodologi Pengajaran Bahasa Arab. Malang: Misykat

Hadi, Amirul. (2005). Metodologi Penelitian Pendidikan. Bandung: Pustaka Setia.

Jamra, Syaiful Bahri dkk. (2002). Strategi belajar mengajar. Jakarta; Rineka cipta. 2000

Muhtadi Ansor, Ahmad. (2009). Pengajaran Bahasa Arab Media, dan Metode-metodenya. Yogyakarta: Teras.

Nuha, Ulin. (2012). Metodologi Super Efektif Pembelajaran Bahasa Arab. Jogjakarta: Diva Press

Nurjamal, Daeng. (2011).Terampil berbahasa. Bandung: Alfabeta.

Rasjid, Sulaiman. (2018). Fiqh Islam.Bandung: Sinar Baru Algensindo.

Rostiyah, NK. (2008). Strategi Belajar Mengajar. Jakarta: Rineka Cipta

Sanjaya, Wina. (2006). Standar Pembelajaran Berorientasi S tandar Proses Pendidikan Edisi Pertama. Jakarta: Kencana Prenada Media Group

Slameto. (1995). Belajar Dan Faktor-Faktor Yang Mempengaruhi. Sinar Baru: Algesindo

Sudjana, Nana (1989). Dasar-dasar Proses Belajar Mengajar. Bandung: Sinar Biru

Sudjana, Nana. (1998). Cara Belajar Siswa Aktif Dalam Proses Belajar Mengajar, Bandung: Sinar Baru

Sudjono, Anas. (1996). Pengantar Statistika Pendidikan. Jakarta: Raja Grafindo persada.

Sugiyono. (2012). Metode Penelitian Kuantitatif dan Kualitatif. Bandung: Alfabeta.

Sukmadinata, Nana Syaodih. (2011). Metode Penelitian Pendidikan. Bandung: Remaja Rosdikarya

Suprapto, Tommy. (2009). Pengantar Teori dan Menejemen Komunikasi. Yogyakarta: MedPress

Syah, Muhibbin. (2003). Metodologi Psikologi Pendidikan. Bandung: PT. Remaja Rosdakarya

Tayar Yusuf dan Syaiful Anwar. (1972). Metodologi Pengajaran Agama dan Bahasa Arab. Jakarta: PT Raja Grafindo Persada

Usman, Basyirudin. (2002). Metodologi Pembelajaran Agama Islam. Jakarta: Ciputat Pres

Zuhairini, dkk. (1983). Matodik Khusus Pendidikan Agama. Surabaya: Usaha Nasional 